\title{
COMPLETING THE FACULTY DEVELOPMENT CYCLE
}

\author{
USING DATA FROM SYLLABI REVIEW TO \\ INFORM ACTION
}

Phyllis Blumberg, University of the Sciences in Philadelphia

Consistent with the mission of the University of the Sciences in Philadelphia, the Teaching and Learning Center has emphasized implementation of learner-centered practices for eight years. To assess the impact of these development efforts, I reviewed syllabi and course approval forms of seventy-two recently approved courses. The documents revealed a disappointing lack of evidence of learner-centered course design features. Voluntary faculty development programming cannot force faculty to change their course designs. However, the results prompted discussions with administrators and faculty and yielded calls to action for greater implementation of learner-centered practices.

Assessing the impact of one's work is a core principle of effective practice. Once informed by the results of these assessments, we can decide if we need to make changes in what we do (Suskie, 2004). As faculty developers, we work individually with faculty, offer workshops, and coordinate learning communities. Researchers have looked at the effectiveness of the process and format of development efforts (Cox, 2004; Sorcinelli, 1997). The most common measures ask participants immediately after programs or consultations how effective the event was. While individual workshops may not have much impact, a sustained effort focusing on a consistent message, with many follow-ups with faculty individually, usually has a greater impact (Cox, 2004; Eison \& Stevens, 1995).

I adapted Suskie's (2004) teaching-learning-assessment cycle to investigate the long-term effects on course design of eight years of sustained faculty 
development efforts. Suskie's cycle begins with faculty development goals, which lead to learning opportunities whose impact is measured by assessment and whose results inform the redefinition of goals and a plan for action. I employed a variety of learning opportunities to assist faculty in implementing the institution's goal of learner-centered teaching (Weimer, 2002). I evaluated the impact of these efforts by determining the learnercentered status of course design features in a sample of courses. I used the results of this assessment to define new goals, further learning opportunities, and action steps for myself, decision makers, and the faculty.

University of the Sciences in Philadelphia is a private institution of about three thousand students and 175 full-time faculty members. More than 85 percent of the operating budget comes from tuition dollars, and effective teaching is valued and evaluated. Part of the university's mission statement is, "The University will provide a student centered learning and living environment." Faculty members define student-centered learning as learnercentered teaching. To be consistent with the university's mission and because a great deal of research supports the idea that learner-centered approaches lead to improved learning (Fink, 2003; Weimer, 2002), I focused on helping faculty members implement this approach to teaching.

\section{Faculty Development Goals}

During the 2001-2002 academic year, a strategic planning process identified six strategic imperatives (University of the Sciences in Philadelphia, 2002), of which one was the development of a culture of student-centered learning and living. The tactical planning group on student-centered learning and living, of which I was a member, defined objectives, developed future action steps, and outlined outcome indicators. The faculty members of the task force raised concerns about the phrase student-centered learning because it seems to focus on customer satisfaction (Weimer, 2002). The faculty members of the task force and I successfully argued for a change in nomenclature to learner-centered teaching, which keeps the emphasis on the students as learners while giving faculty an important role in this learning. While this change may seem like wordsmithing, it was important in promoting acceptance of the planned change in culture.

The tactical planning group identified (among others) the following key outcome indicators of the learner-centered strategic imperative: faculty, staff, and administrators will know what learner-centered teaching entails and how to achieve it; and the curriculum will be consistent with learner-centered teaching in terms of development, content, and delivery (University of the Sciences in Philadelphia, 2002). This study focuses on assessing the achievement of the second indicator. 


\section{Learning Opportunities}

The Teaching and Learning Center was charged with directing the education needed to achieve the key outcome indicators of learner-centered teaching. Throughout 2002-2003, the center hosted activities focusing on learner-centered teaching, including four day-long workshops given by experts in learner-centered teaching and sixteen discussions. With the combined recruiting efforts of administrators and chairs and my heavy promotion of these workshops, about 70 percent of the faculty attended at least one of these workshops, and the majority of these faculty attended at least two.

At the end of 2003, the center hosted a conference, attended by onethird of the faculty, to define learner-centered teaching and suggest how faculty could achieve it. Participants agreed that the essential aspect of learner-centered teaching was students' taking responsibility for their own learning, and they agreed that faculty needed to facilitate students' progress toward this desired end. The faculty agreed that implementing learner-centered teaching required them to redesign their learning goals, outcomes, teaching and learning activities, and assessments. There could be multiple ways to achieve learner-centered teaching, but they all involved actively engaging the students in their learning (Blumberg $\&$ Everett, 2005). From the conference, I developed a consensus statement of the faculty's views of learner-centered teaching, which I used in planning for future educational efforts.

In 2003-2004 I coordinated a learning community for ten faculty members from across the university to explore in depth how to implement learner-centered teaching and design learner-centered courses. These faculty were expected to serve as trainers for others in their departments, sharing with their peers how they changed their teaching and working with individuals who wanted to implement learner-centered teaching.

In the following years, from 2004 to 2009 , I continued educating faculty about learner-centered teaching and highlighting local examples of its implementation. Annually since 2003, all new faculty members have participated in a hands-on workshop on teaching, lasting a day and a half, using learner-centered approaches to course design. I offered at least twelve short hands-on workshops each year that focused on aspects of learner-centered teaching such as how to get students to take responsibility for their learning and the varied uses of assessment to guide improvement. All of these workshops allowed time for faculty to alter an aspect of their existing courses. About half of the faculty attended at least one of these workshops each year, and several people attended many of them. 
The feedback from these workshops was that they were helpful in fostering implementation of learner-centered teaching. During this five-year period, the center hosted well-attended poster sessions that featured examples of faculty using learner-centered approaches (Blumberg, 2004).

In feedback on these events, faculty said that they developed a sense of community as teachers (Millis, 1997). It appeared that interest in using learner-centered teaching was growing (Blumberg, 2004). There seemed to be good reason for optimism that faculty members were implementing learner-centered practices.

\section{Assessment Methodology}

To complete Suskie's (2004) cycle, I assessed the impact of these faculty development efforts on course design by assessing the learner-centered status of a sample of courses at the point of course (re)approval.

\section{Course Selection Criteria and Sample Size}

The faculty approved a new general education curriculum in 2007. In addition to disciplinary knowledge, the courses in the new curriculum were required to teach skills that transcend the disciplines, including critical reasoning and problem solving, information literacy, oral and written communication, and technology. All courses in the new curriculum had to be (re)approved by a curriculum committee. I selected these courses for review because the approval process could be expected to give faculty an opportunity to revise the course to meet the new general education requirements and incorporate learner-centered approaches. All general education courses were considered with the following additional selection criteria: the second course of a year-long sequence was selected for review, all one-semester courses were reviewed, and the syllabus of one section of a multisection course was randomly chosen to be reviewed. Seventy-two small and large enrollment courses met these criteria and were reviewed.

\section{Course Review and Analysis Process}

Shulman (2004) suggests using course syllabi as a means to understand how courses work since they represent a form of scholarship about an individual's teaching and course design. A preliminary review of a few syllabi indicated that they addressed the course design elements of learner-centered 
teaching. With approval from the university's Institutional Review Board, during 2009 I requested syllabi for the selected courses from course instructors and department chairs. I reviewed the course approval form and the most recent version of the syllabus to determine the learner-centered status of each course. The course approval form requires the instructor to list which of the five general education skills the course would address, objectives for these skills, teaching and learning methods to help students master these skills, and how these skills would be assessed. Assessing syllabi and course approval forms for learner-centered elements is not the same as assessing the course, but taken together, the two documents provide a relatively complete picture of the relevant elements of course design.

\section{Assessing Learner-Centered Approaches to Course Design}

Weimer (2002) described five practices that need to change to achieve learner-centered teaching: content, instructor's role, responsibility for learning, purposes and processes of assessment, and the balance of power. Blumberg (2009) further defined Weimer's (2002) five practices with specific instructor behaviors that altogether result in a set of twentyfive descriptive components of learner-centered teaching behaviors (Exhibit 14.1). Blumberg (2009) developed a rubric for each of the five practices by listing their components separately in rows. Each rubric identifies four levels of practice for each component: instructor-centered teaching, learner-centered teaching, and two intermediate levels (called lower and higher level of transition) between the two poles. The rubrics were used to rate the degree to which a course was learner-centered. Exhibit 14.2 gives a sample rubric for two components (complete rubrics can be found in Blumberg, 2009).

\section{Exhibit I 4.I Learner-Centered Components Grouped According to Weimer's Practices}

\section{The Function of Content}

1. Varied uses of content: In addition to building a knowledge base, instructor uses content to help students know why they need to learn content, acquire discipline-specific learning methodologies, use inquiry or ways of thinking in the discipline, and learn to solve real world problems

2. Level to which students are engaged in content

3. Use of organizing schemes

4. Use of content to facilitate future learning 
THE ROLE OF THE INSTRUCTOR

1. Creation of a environment for learning through organization and use of material that accommodates different learning styles

2. Alignment of the course components-objectives, teaching or learning methods, and assessment methods-for consistency

3. Teaching or learning methods appropriate for student learning goals

4. Activities involving interactions of student, instructor, and content

5. Motivation of students to learn (intrinsic drive to learn versus extrinsic reasons)

\section{THE RESPONSIBILITY FOR LEARNING}

1. Responsibility for learning-a philosophical overview

2. Learning to learn skills for the present and the future, for example, time management, goal setting, and how to do independent reading and research

3. Self-directed, lifelong learning skills, for example, determining a personal need to know more, knowing who to ask or where to seek information, determining when the need is met, and developing an awareness of a student's learning abilities

4. Students' self-assessment of their learning

5. Students' self-assessment of their strengths and weaknesses

6. Information literacy skills (Association of College and Research Libraries, 2004)

\section{Processes and Purposes of Assessment}

1. Assessment within the learning process

2. Formative assessment

3. Peer and self assessment

4. Demonstration of mastery and ability to learn from mistakes

5. Authentic assessment

\section{The Balance of Power (Control Issues)}

1. Determination of course content

2. Determination of how students earn grades

3. Use of open-ended assignments

4. Flexibility of course policies, assessment methods, learning methods, and deadlines

5. Opportunities to learn

Note: From Blumberg (2009). Reprinted with permission of John Wiley \& Sons, Inc. 


\section{Exhibit 14.2 Sample Rubrics and Scoring Index for Two Components for the Responsibility for Learning Practice}

\begin{tabular}{|c|c|c|c|c|}
\hline \multirow{3}{*}{$\begin{array}{l}\text { Likert Scale } \\
\text { Scoring Index }\end{array}$} & \multirow{2}{*}{$\begin{array}{l}\text { Employs } \\
\text { Instructor- } \\
\text { Centered } \\
\text { Approaches }\end{array}$} & \multicolumn{2}{|c|}{$\begin{array}{l}\text { Transitioning to Learner- } \\
\text { Centered Approaches }\end{array}$} & \multirow{2}{*}{$\begin{array}{l}\text { Employs } \\
\text { Learner- } \\
\text { Centered } \\
\text { Approaches }\end{array}$} \\
\hline & & $\begin{array}{l}\text { Lower Level of } \\
\text { Transitioning }\end{array}$ & $\begin{array}{l}\text { Higher Level of } \\
\text { Transitioning }\end{array}$ & \\
\hline & 1 & 2 & 3 & 4 \\
\hline $\begin{array}{l}\text { Component 4: } \\
\text { Students' self- } \\
\text { assessment of } \\
\text { their learning }\end{array}$ & $\begin{array}{l}\text { Instructor } \\
\text { believes that } \\
\text { instructors } \\
\text { alone assess } \\
\text { student } \\
\text { learning }\end{array}$ & $\begin{array}{l}\text { Instructor does } \\
\text { not direct stu- } \\
\text { dents to assess } \\
\text { their own } \\
\text { learning }\end{array}$ & $\begin{array}{l}\text { Instructor } \\
\text { sometimes } \\
\text { provides direc- } \\
\text { tion to help } \\
\text { students assess } \\
\text { their own } \\
\text { learning }\end{array}$ & $\begin{array}{l}\text { Instructor } \\
\text { motivates } \\
\text { students to } \\
\text { routinely and } \\
\text { appropriately } \\
\text { assess } \\
\text { their own } \\
\text { learning }\end{array}$ \\
\hline $\begin{array}{l}\text { Component 6: } \\
\text { Information } \\
\text { literacy skills } \\
\text { as defined by } \\
\text { the Associa- } \\
\text { tion of College } \\
\text { and Research } \\
\text { Libraries } \\
\text { (2004) }\end{array}$ & $\begin{array}{l}\text { Instruc- } \\
\text { tor does } \\
\text { not help } \\
\text { students } \\
\text { acquire any } \\
\text { informa- } \\
\text { tion literacy } \\
\text { skills }\end{array}$ & $\begin{array}{l}\text { Instructor } \\
\text { helps students } \\
\text { acquire a few } \\
\text { information } \\
\text { literacy skills }\end{array}$ & $\begin{array}{l}\text { Instructor } \\
\text { helps students } \\
\text { acquire some } \\
\text { information } \\
\text { literacy skills }\end{array}$ & $\begin{array}{l}\text { Instructor } \\
\text { facilitates } \\
\text { students to } \\
\text { become profi- } \\
\text { cient in all five } \\
\text { information } \\
\text { literacy skills }\end{array}$ \\
\hline
\end{tabular}

Source: From Blumberg (2009). Reprinted with permission of John Wiley \& Sons, Inc.

Using Blumberg's (2009) rubrics, I rated each course on its learnercentered approaches for all twenty-five components. For example, I used various types of evidence to support my rating on the last component of the responsibility for learning practice, which is information literacy. To rate a course on this component, I looked for evidence in the course approval form or the syllabus that the instructor was helping students acquire information literacy skills. If there were no assignments for which the students had to gather information on their own and there were no writing assignments, I rated the course at the instructor-centered level (1). If the course schedule included a class devoted to searching appropriate databases, I knew that at least a few information literacy skills were taught. If there were writing assignments, I looked for statements about plagiarism in the syllabus or a practice exercise on paraphrasing as evidence 
that the instructor was helping the students gain the information literacy skill of using information ethically and legally.

\section{Data Analysis}

Rubrics can be seen as a series of Likert scales and numbers can be assigned to the levels (Exhibit 14.2). I assigned the following numbers to the levels on the rubrics: 1 = instructor centered, 2 = lower level of transition, 3 = higher level of transition, and $4=$ learner centered. If I could not determine the level of the component from the syllabus and course approval forms, I assigned it a 1 . I was unable to determine the level on fewer than 4 percent of the components across all courses. I recorded on spreadsheets the ratings for each component of each course.

I created a learner-centered index for each course (summative scale) by taking the sum of the scores assigned to each of the components divided by twenty-five (the total number of components considered). The range of the index is from 1 to 4 , with the higher number indicating a more learner-centered course. I also created learner-centered indexes for each of the five practices.

Courses were classified according to how often their instructors used the services of the center. Instructors who attended more than 50 percent of the long workshops hosted by the center or met with the director on a regular basis to discuss their teaching were considered high users. Those who attended 25 to 50 percent of the major events hosted by the center or met with the director a few times a year to discuss their teaching were considered medium users. Low users were those who came to fewer than 24 percent of these events and rarely or never consulted with the director about their teaching or course design.

\section{Assessment Results}

The learner-centered indexes of the seventy-two courses reviewed clustered in the lower (instructor-centered or lower level of transition) range of the scale (Figure 14.1). Only one course had a high index (above 3.0), thirty-five had indexes between 2.0 and 3.0 , and the remaining thirtysix courses ( 50 percent) had indexes between 1 and 2 . Thus, most of the courses hover around the lower level of transition with respect to learnercentered course design. It should be noted that although a course might be rated in the lower level of transition overall, there were variations in the ratings for each component within each course. Some components, such as level of student engagement, tended to be rated more learner 
Figure I4.I Learner-Centered Index for Seventy-Two Courses

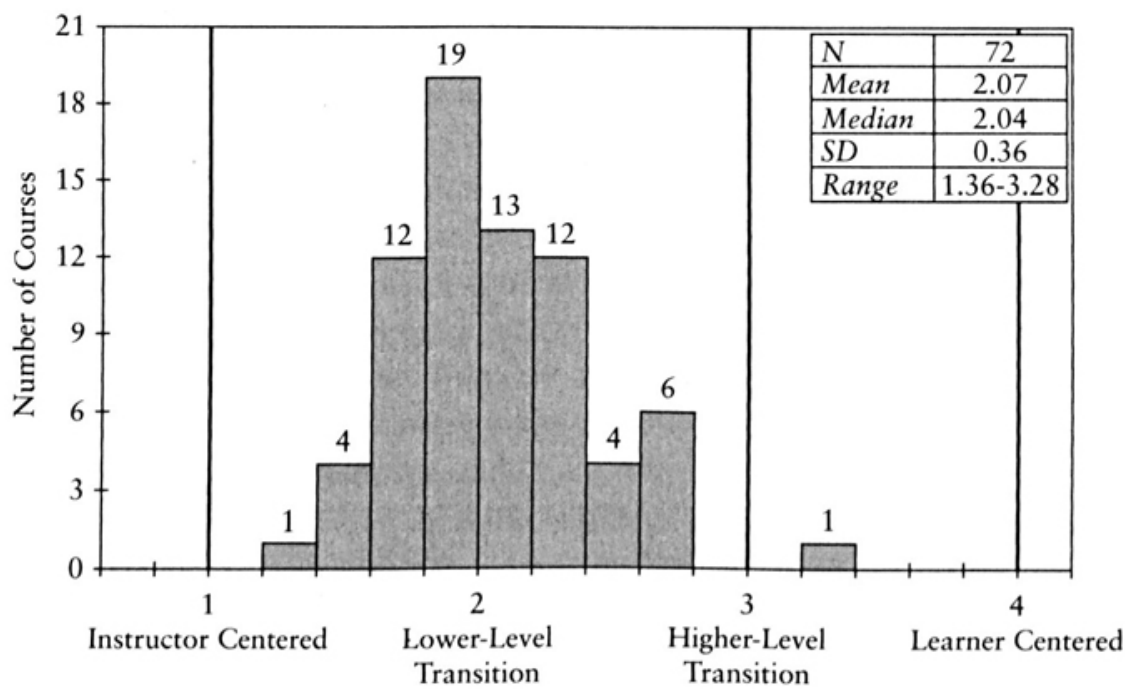

centered, and some components, such as teaching the skills necessary for students to take responsibility for their own learning, were generally rated more instructor centered. The mean index for the responsibility for learning components was 1.98 , also around the lower level of transition, and fifty-four of seventy-two ( 75 percent) courses had a responsibility for a learning index between 1 and 2 .

Based on a one-way ANOVA test I concluded that the average learnercentered index does not differ significantly among the departments in which I reviewed more than five courses. I used two separate two-sample $t$-tests to test for a difference in average learner-centered index between full-time and adjunct faculty and for a difference in average learnercentered index for faculty teaching less than five years and those teaching five or more years. Based on these tests, I concluded that the average learner-centered index for full-time faculty does not significantly differ from the one for adjunct faculty, and there were no significant differences among faculty depending on their years of experience.

Figure 14.2 compares the learner-centered status of courses taught by high $(N=11)$, medium $(N=7)$, and low $(N=54)$ users of the center's services. The mean learner-centered index for high users is higher than the one for nonusers. A significant difference between at least two categories of center users was confirmed by a one-way ANOVA test $(p=0.0013)$. Based on a post hoc analysis conducted using Bonferroni adjustment, there is a significant difference between high and low users $(p<0.05)$. 
Figure I4.2 Comparison of Learner-Centered Indexes for Courses Taught by High, Medium, and Low Users of the Teaching and Learning Center

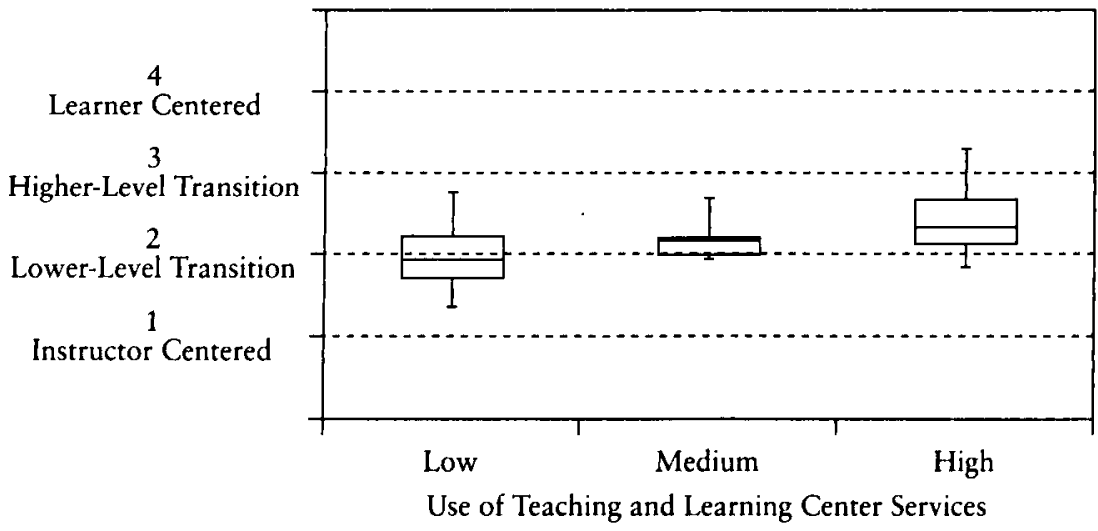

Note: The bottom of the whisker is the lowest value, the lowest line of the box is the lower quartile (twenty-fifth percentile), the middle line in the box is the median, the top line of the box is the upper quartile (seventy-fifth percentile), and the top of the whisker is the highest value.

\section{Limitations of This Study}

There is no baseline study of the learner-centered status of courses prior to the learner-centered strategic initiative. Therefore, this study cannot infer that any changes were made; it can only determine the status of course designs at the time of this review. Only one person rated each of the courses on the components listed on the rubrics. The ratings were not checked with the instructors of the courses. There was no validation that the contents of the syllabus and the course approval form reflected what the instructor actually did in the course. A majority of the courses are introductory courses taught to first- and second-year students; a study of upper-division courses might well yield different results.

Although the study found that courses taught by frequent center users employed more learner-centered approaches than others, it does not establish a cause-and-effect relationship. The unanswered question is, "Were these frequent users predisposed to this philosophy of teaching and course design prior to learning specific techniques, or did these workshops persuade them to change their approach?"

\section{Using the Results: Action Steps}

Individually and in groups, I discussed the study, its results, and implications of the results with the provost, deans, appropriate department chairs, and faculty committees. Each presentation began with the relevant 
part of the university's mission statement to remind them that we were supposed to be using learner-centered approaches. I pointed out that the eight years of focused efforts by the center with many faculty attending workshops did not result in many courses using predominantly learnercentered course design elements. The fact that the high users of the center implemented significantly more learner-centered course design elements showed that faculty could implement learner-centered course design at the university even in general education courses. These discussions always led faculty to consider specific ways they could improve their syllabi.

My reports emphasized possible next steps that this university could take to become more learner centered. I described concrete steps that individual faculty members could take, such as teaching students how to use or requiring them to do more self-assessments of their learning and their strengths. My reports contained specific, inexpensive policy recommendations, such as the following: "Faculty need to be evaluated on how learner-centered their teaching actually is. This is not part of the current annual faculty evaluation or promotion and tenure process. Until it is, many faculty members will have little reason to change their teaching."

\section{Further Goals and Actions}

The dean of the College of Arts and Sciences (where most of these courses are housed) was interested in the results of this study. She felt that courses in her college should incorporate more aspects of learner-centered teaching and course design because it is consistent with her vision of a liberal arts education. My study prompted the college's strategic planning committee to discuss how learner-centered teaching and course design fit with their vision. As a result, learner-centered teaching is now explicitly mentioned in that college's strategic plan. The plan mentions a few broad-stroke methods, but most of the actual steps will be defined by the tactical planning task force. Since the dean asked me to serve on that task force, I am confident that I will be able to incorporate appropriate specific steps. These steps might identify which components need to be emphasized in a general education curriculum and which might be more appropriate to advanced courses.

At the beginning of 2010, I offered several workshops on how to implement specific aspects of learner-centered teaching, and the dean strongly encouraged her faculty to attend. Next, with her encouragement, I plan to work with individual departments at their meetings. The dean and I are planning a collegewide event to help faculty implement learnercentered course design. Through these steps, more faculty members could 
design their courses using specific learner-centered strategies, and perhaps even more critical, they will realize why they need to use learner-centered approaches.

My next step is to interview some faculty whose syllabi and course approval forms I reviewed. These interviews will serve two purposes. First, I can determine whether my ratings for their courses are accurate. Second, and more important, is to begin to discuss steps toward specific changes to their teaching and course design.

\section{Discussion}

At this university, learner-centered teaching and course design are explicitly mentioned in the mission statement, a strategic imperative adopted by the university, and detailed action steps identified by a tactical planning group. The Teaching and Learning Center has focused on how to implement learner-centered teaching and course design for almost a decade. Yet the results of the study indicated that faculty members were not implementing learner-centered teaching. The consistently low ratings for all components showed that faculty had not aligned their course designs to be consistent with the university's mission, their own statements formed during the consensus conference, or faculty development efforts.

At first I was quite discouraged with these results. For a short time, I even took them personally as this is a small university and I know every faculty member. Since faculty developers are in the habit of solving problems, I thought about possible changes in my faculty development practices. In the future, I will do more one-on-one follow-up after workshops. I will not assume that faculty both heard the message and know how to implement changes.

I speculate that most faculty members did not implement learner-centered course design for a variety of reasons. While the center offered many educational opportunities for faculty to learn about learner-centered teaching and course design and the administration fully supported learner-centered teaching, no real incentives were provided to implement it. Faculty were not given release time to revise their courses. The student course evaluations continued to ask about traditional instructor behaviors such as the effectiveness of presenting the material. Annual evaluations of faculty or those for promotion and tenure did not mention learner-centered teaching or course design. As the ratings of the courses taught by the high users of center services indicate, faculty can learn to change their teaching practices and course design. However, many probably need to be convinced to do so by either pressure or significant rewards. 
Voluntary faculty development efforts such as those offered by teaching and learning centers cannot move the majority of an institution's faculty to implement learner-centered teaching and course design without a parallel effort to change the institution's collective policies, structures, and individual beliefs. To truly achieve implementation of unfamiliar teaching philosophies and practices, we need to have a concrete plan for widespread culture change. For example, many faculty members may need support to spend a significant amount of time revising their course design. Such support might take the form of teaching fellowships with faculty working together with the faculty developers, release time, or summer pay. Most of these changes can occur only through administrative decisions and actions.

\section{Conclusion}

Disappointing results can be the stimulus for change if they are used properly. In our assessment and accountability culture, coupling data with concrete and specific recommendations provides the impetus for change. The process I describe in this chapter points to the importance of assessing the impact of our work not only as a scholarly activity for our own publications, but also to inform discussions with key decision makers as part of the faculty development assessment cycle.

\section{REFERENCES}

Association of College and Research Libraries. (2004). Information literacy competency standards for higher education. Retrieved from www.ala.org /ala/acrl/acrlstandards/informationliteracycompetency.htm

Blumberg, P. (2004). Beginning journey toward a culture of learning centered teaching. Journal of Student Centered Learning, 2(1), 68-80.

Blumberg, P. (2009). Developing learner-centered teaching: A practical guide for faculty. San Francisco: Jossey-Bass.

Blumberg, P., \& Everett, J. (2005). Achieving a campus consensus on learning-centered teaching. In S. Chadwick-Blossey \& D. R. Robertson (Eds.), To improve the academy: Vol. 23. Resources for faculty, instructional, and organizational development (pp. 191-210). San Francisco: Jossey-Bass/Anker.

Cox, M. D. (2004). Introduction to faculty learning communities. In M. D. Cox \& L. Richlin (Eds.), Building faculty learning communities (pp. 5-23). San Francisco: Jossey-Bass.

Eison, J., \& Stevens, E. (1995). Faculty development workshops and institutes. In W. A. Wright (Ed.), Teaching improvement practices: Successful strategies for higher education (pp. 206-236). San Francisco: Jossey-Bass/Anker. 
Fink, L. D. (2003). Creating significant learning experiences: An integrated approach to designing college courses. San Francisco: Jossey-Bass.

Millis, B. (1997). Evaluating a consultation program for parttime adjunct faculty. In K. T. Brinko \& R. J. Menges (Eds.), Practically speaking: A sourcebook for instructional consultants in bigher education (pp. 245259). Stillwater, OK: New Forums Press.

Shulman, L. S. (2004). Teaching as community practice. San Francisco: Jossey-Bass.

Sorcinelli, M. D. (1997). The teaching improvement process. In K. T. Brinko \& R. J. Menges (Eds.), Practically speaking: A sourcebook for instructional consultants in higher education (pp. 157-158). Stillwater, OK: New Forums Press.

Suskie, L. (2004). Assessing student learning: A common sense guide. San Francisco: Jossey-Bass/Anker.

University of the Sciences in Philadelphia. (2002). Strategic planning document. Unpublished document.

Weimer, M. (2002). Learner-centered teaching. San Francisco: Jossey-Bass. 